\title{
Edyta Zawadzka
}

The Maria Grzegorzewska

Academy of Special Education in Warsaw

\section{SHYNESS IN CASE OF CONTEMPORARY TEENAGERS-SPECIFICITY OF THE PHENOMENON AND WAYS OF SUPPORTING SHY ADOLESCENTS}

\section{Introduction}

The contemporary reality and the culture are very demanding for human beings. The man should be self-confident, outgoing, communicative, creative, independent... and has many others features. In addition, a person has a duty to experience pleasure and joy, to possess the material goods, to achieve success, to exist in the immediacy and to be prepared for continuous changes (Melosik, 2005, 2007). Moreover in the twenty-first century, the main ways of communication have become instant messengers and mobile phones.

At the same time family has ceased to give a young man support. Parents often work long hours and often understand upbringing as the satisfying the material needs of the child. Grandparents because of poor health, lack of desire or remoteness often aren't available to teenagers. At the same time the prefigured culture exists (Mead, 2000), which one of the most important feature is a fact, that the young generation is a guide to elder in the modern world.

It seems that in case of teenagers the implications of above constituent elements of contemporary culture are significant. They may contribute to appear sense of inadequacy and discrepancy between who they are and who according to cultural standards, ought to be. In addition, the teenagers were not equipped, especially by the family, in the basic tools to function effectively in the modern reality, but also in interpersonal relationships. The multiplicity of indirect contacts causes human impoverishment of social skills. These consequences in the context of teenagers are reinforced by the specificity of a very difficult period of adolescence. We cannot be forgotten that this is the time when the safe world of childhood declines and a person begins to become an adult. It is associated with many changes in all human developmental spheres. 
It seems that it is an excellent base to occur or worsen of shyness during this period. Therefore the main goal of the empirical investigation, which was shown in this paper, was to analyze this phenomenon in case of contemporary teenagers.

\section{Shyness - a Theoretical Background}

Shyness is an ambiguous concept, having many definitions, used both in the scientific literature and in everyday language. In the Little Dictionary of Polish Language (p. 504) shyness is defined as follows - "lack of courage and confidence, bashfulness, intimidation, embarrassment". Understanding the word in this context is characteristic for everyday language and people who do not delve into the essence of this concept, interpreting it quite superficial.

In the scientific literature are presented two points of view regarding shyness (Borecka-Biernat, 2001). The first one highlights the specificity of the shy people in the field of behavioral and emotional spheres, usually emphasizing the role only one of them. The behavioral aspect of shyness is described at the level of behavior, in the definitions are emphasized the most external symptoms, readily available for observation, e.g. reduction in the level of human functioning in situations in which somebody and someone's activity is the object of interest (Borecka - Biernat, 2001). In another aspect - emotional, shyness is understood as a specific form of anxiety, which content is the prediction of personal threat in the form of negative social assessment especially at moments of public exposure and the actual assessment (Borecka-Biernat, 2001; Gerstmann, 1963; Paryzek, 1974). Supporters of the second point of view, understand shyness as a team of specific symptoms associated with disorder in the behavioral, emotional and motivational fields and caused and reinforced by the presence of other people. In this context social passivity, social anxiety, low self-esteem and lack of self-confidence are especially characteristic for shy people (Zabłocka, 2008).

Modern scientists - P.G.Zimbardo (2008) and B.Carducci (2008) because of the complexity of shyness decided not to define it. In their opinion any single definition isn't adequate. Their views on shyness is best expressed in B. Carducci's words (2008, p .19): "if you consider yourself a shy person, you're shy". The same assumption was adopted in research, which results are presented in the paper. Therefore the respondents didn't receive any particular definition, they were allowed to adopt their own understanding of the term.

Analyzing the scientific literature regarding shyness, we can find various proposals on types of this phenomenon. However in the paper, I presented only the typology by P.G. Zimbardo and P. Pilkonis (2008) who distinguished public and private shyness, because it is highly appropriate to specificity of shyness in case of contemporary teenagers. The first type of shyness (public) is associated with 
public self-awareness, which symptom is person's concern about opinions about $\mathrm{him} /$ her. People with this kind of self-awareness constantly consider what others think about them, whether they are popular and are also concerned about the style of their action. Such people, closing themselves in their isolated world, deprive themselves of opportunities to tell others of their merits, desires, concerns and experience of love, recognition and assistance. Private shyness is associated with private self-awareness which is manifested as negative focus on oneself. People with this type of self-awareness spend a lot of time thinking about themselves, constantly analyze and try to understand themselves and own motives. They are heroes of their fantasies, are sensitive to own feelings and changes in mood. They have awareness how the brain works to solve the problem. People with this type of shyness are often not perceived as such by other people, if they are suitably competent, can achieve success both in society and in professions requiring social exposure (e.g. actors, journalists). Many of them learnt to hide fears using well-trained social skills or to avoid situations in which they would not have full control. However, action, which they take are accompanied by malaise and fear that someone discovers what they want. Moreover they cannot enjoy their own successes. People with this type of shyness are often perceived by others as bossy, using others, haughty. Both types of shyness may occur together or alone (Harwas-Napierala, 1995).

Shyness can cover a broad psychological continuum - from the only sometimes (in the presence of other people) experienced feelings of embarrassment to traumatic periods of fear, completely destroying person's life. At the one end of the continuum are people who prefer to be among books, nature, objects and immerse into their thoughts than to contact with people. This group is internally varied - it can be distinguished both easily establish relationships and those for who every social interaction is a problem that causes tension. The middle compartment includes the largest group of people. They are characterized by confusion and intimidation in some situations and relationships with some categories of people. However the intensity of their embarrassment is so strong that it causes disruptions in their social life and inhibits their behavior. At the edge of shyness continuum are those whose fear of other people is boundless. These people experience huge fear in situations requiring them to do something in the eyes of others. Then they become powerless. They see their salvation in escaping or in hiding. In the most extreme cases, shyness can become a serious form of neurosis, paralysis of the mind, which can lead to depression and suicide decision (Zimbardo, 2008).

L. Henderson and P. Zimbardo (2011) presented four groups of symptoms of shyness: behavior, physiological, cognitive and affective. Behavior symptoms are: inhibition and passivity, gaze aversion, avoidance of feared situations, low speaking voice, little body movement or expression or excessive nodding or 
smiling, speech dysfluencies nervous behaviors, such as touching one's hair or face. Physiological symptoms are: accelerated heart rate, dry mouth, trembling or shaking, sweating, feeling faint or dizzy, butterflies in stomach or nausea, experiencing the situation or oneself as unreal or removed, fear of losing control, going crazy, or having a heart attack. Cognitive symptoms are: negative thoughts about the self, the situation, and others, fear of negative evaluation and looking foolish to others, worry and rumination, self-blaming attributions, particularly after social interactions, negative beliefs about the self (weak) and others (powerful), often out of awareness, negative biases in the self-concept, e.g., "I am socially inadequate, unlovable, unattractive", a belief that there is a "correct" protocol that the shy person must guess, rather than mutual definitions of social situations. Affective symptoms are: embarrassment and painful self-consciousness, shame, low self-esteem, dejection and sadness, loneliness, depression, perfectionism.

Shyness is a phenomenon which, in scientists' opinion may be the result of many different factors. They say about three groups of causes - conditioned by biological factors, personality and environmental (both social and family) (Borecka - Biernat, 2001; Carducci, 2008; Harwas-Napierała, 1979, 1995; Kędzierska, Znajmiecka - Sikora, Kaflik - Pieróg, 2002, 2003; Zabłocka, 2008, Zimbardo, 2008).

\section{Research Questions}

In order to achieve the main goal of empirical investigation, which is an analysis of shyness in case of teenagers, developed research questions focused on the following issues:

- criteria, which teenagers use, when they decided about considering themselves shy

- prevalence of shyness;

- intensity of shyness;

- stability/variability of experiencing shyness;

- attitude toward shyness;

- circumstances of experiencing shyness.

\section{Research Tool}

The research tool was a questionnaire, which consists of two main parts. Part I is slightly modified the Stanford Shyness Survey by P. Zimbardo adapted by Kędzierska, Znajmiecka-Sikora and Kaflik - Pieróg, consisting of three smaller parts marked with Arabic numerals. Part II contained questions prepared myself 
focused on various spheres of adolescents' life. However in this paper because of its volume, data from Part II, weren't presented. The questionnaire consisted of both closed questions where the respondent answer "yes" / "no", chose one, two or more responses from those given, as well as open, in which respondents fill in specific words, sentences and numerical values. Teenagers had positive attitude to research and could fill in questionnaire leisurely.

\section{Research Sample}

289 students of Lodz secondary schools participated in the research. However 25 questionnaires were rejected, because these respondents didn't answer the most important questions. Therefore analysis presented in the paper, is based on the responses of the 264 people. table 1 shows the exact characteristics of research sample.

Table 1. Characteristic of research sample

\begin{tabular}{|c|c|c|c|c|c|c|}
\hline & \multicolumn{2}{|c|}{ women } & \multicolumn{2}{|c|}{ men } & \multicolumn{2}{|c|}{ Total } \\
\hline & $\mathrm{n}$ & $\%$ & $\mathrm{n}$ & $\%$ & $\mathrm{~N}$ & $\%$ \\
\hline \multicolumn{7}{|l|}{ Age } \\
\hline 16 & 55 & 36.91 & 42 & 36.52 & 97 & 36.74 \\
\hline 17 & 58 & 38.93 & 29 & 25.22 & 87 & 32.95 \\
\hline 18 & 26 & 17.45 & 31 & 26.96 & 57 & 21.59 \\
\hline 19 & 9 & 6.04 & 12 & 10.43 & 21 & 7.95 \\
\hline 20 & 1 & 0.67 & 1 & 0,87 & 2 & 0.76 \\
\hline \multicolumn{7}{|l|}{ Type of school } \\
\hline general secondary school & 56 & 37.58 & 40 & 34.78 & 96 & 36.36 \\
\hline profiled secondary school & 13 & 8.72 & 5 & 4.35 & 18 & 6.82 \\
\hline technical secondary school & 53 & 35.57 & 48 & 41.74 & 101 & 38.26 \\
\hline vocational school & 27 & 18.12 & 22 & 19.13 & 49 & 18.56 \\
\hline \multicolumn{7}{|l|}{ Place of residence } \\
\hline Village & 7 & 4.70 & 5 & 4.35 & 12 & 4.55 \\
\hline town (less 10000 inhabitants) & 1 & 0.67 & 3 & 2.61 & 4 & 1.52 \\
\hline town (10 000 to 100000 inhabitans) & 9 & 6.04 & 7 & 6.09 & 16 & 6.06 \\
\hline town (over 100000 inhabitans) & 132 & 88.59 & 100 & 88.96 & 232 & 87.88 \\
\hline
\end{tabular}

Source: Own research 


\section{Characteristic of Shyness in Case of Contemporary Adolescents on the Basis of Conducted Research}

It's essential to notice that in presented analysis was adopted the research perspective, which is proposed by Zimbardo - one of the most well-known researcher of the phenomenon. Therefore, any "objective" indicators that assigned respondents to one of two groups - shy and not shy, weren't used. Respondents were allowed to adopt their own understanding of this term. As a result, teenagers assigned a value (shy/not shy) to a variable themselves. The subject of interest was only the frequency of experiencing shyness as a criterion for considering themselves shy. Therefore, the survey included a question on this issue. The collected data were presented in table 2 .

Table 2. Frequency of experiencing shyness as a criterion for considering themselves shy used by teenagers who presently or in the past experience/experienced shyness

\begin{tabular}{|l|c|c|c|c|c|c|}
\hline & \multicolumn{2}{|l|}{ women } & \multicolumn{2}{l|}{ men } & \multicolumn{2}{l|}{ Total } \\
\cline { 2 - 7 } & $\mathrm{n}$ & $\%$ & $\mathrm{n}$ & $\%$ & $\mathrm{n}$ & $\%$ \\
\hline $\begin{array}{l}\text { experiencing shyness all the time in all } \\
\text { situations }\end{array}$ & 7 & 5.18 & 5 & 5.27 & 12 & 5.22 \\
\hline $\begin{array}{l}\text { experiencing shyness in most situa- } \\
\text { tions (for at least 50\% of the time) }\end{array}$ & 85 & 62.97 & 55 & 57.89 & 140 & 60.87 \\
\hline $\begin{array}{l}\text { experiencing shyness sometimes, but } \\
\text { these moments are sufficiently impor- } \\
\text { tant to consider oneself shy }\end{array}$ & 43 & 31.85 & 35 & 36.84 & 78 & 33.91 \\
\hline
\end{tabular}

$\chi^{2}(2, \mathrm{~N}=230)=0.645, \mathrm{~ns}$.

Source: Own research

Analysis of the data contained in the above Table shows that the largest number of respondents ( $\mathrm{n}=140$ for the total population currently shy or experienced shyness in the past, $\mathrm{n}=85$ for a group of women currently or formerly experience/experienced shyness and $n=55$ for men currently or previously consider/ considered themselves shy) decided to choose the most moderate criterion (experiencing shyness in most situations for at least $50 \%$ of the time), fewer teenagers $(\mathrm{n}=78, \mathrm{n}=43, \mathrm{n}=35)$-relatively mild (experiencing shyness only sometimes), the fewest $(n=12, n=7, n=5)$ - the most extreme (experiencing shyness all the time in all situations). It seems that collected data showed quite rational, realistic and unexaggerated attitude toward shyness.

In order to test significance of relationship between sex and analyzed in Table 2 issue, it was used Crosstabs procedure (in SPSS 14.0$)^{2}$ for a chi square test. As

\footnotetext{
${ }^{2}$ The same procedure was used for all statistical inferences contained in this paper.
} 
we know the significant value of the test, allows to reject null hypothesis (there is no relationship between two analyzed variables) and to accept alternative hypothesis (there is relationship between analyzed variables). The two-sided asymptotic significance is $p=0.724$. Therefore it can be concluded that there is no statistically significant relationship between sex and frequency of experiencing shyness as a criterion considering oneself shy.

The characteristic of shyness in case of contemporary teenagers should also contain information about the prevalence of this phenomenon. In this context, the following issues: experiencing of current and chronic shyness, considering oneself shy in the past and experiencing a sense of intimidation - were analyzed. These data were collected by asking respondents some questions and were presented in table 3.

Table 3. Prevalence of shyness in case of contemporary teenagers

\begin{tabular}{|c|c|c|c|c|c|c|}
\hline & \multicolumn{2}{|c|}{ women } & \multicolumn{2}{|c|}{ men } & \multicolumn{2}{|c|}{ Total } \\
\hline & $\mathrm{n}$ & $\%$ & $\mathrm{n}$ & $\%$ & $\mathrm{n}$ & $\%$ \\
\hline \multicolumn{7}{|l|}{ a. experiencing shyness currently } \\
\hline teenagers, who experience shyness currently & 82 & 55.03 & 54 & 46.96 & 136 & 51.52 \\
\hline $\begin{array}{l}\text { teenagers, who don't experience shyness } \\
\text { currently }\end{array}$ & 67 & 44.97 & 61 & 53.04 & 128 & 48.48 \\
\hline \multicolumn{7}{|l|}{$\chi^{2}(1, N=264)=1.695, \mathrm{~ns}}$. \\
\hline \multicolumn{7}{|c|}{ b. experiencing chronic shyness - in one's life there wasn't a period without feeling shyness } \\
\hline chronic shy teenagers & 49 & 59.76 & 32 & 59.26 & 81 & 59.56 \\
\hline teenagers, whose shyness isn't chronic & 33 & 40.24 & 22 & 40.74 & 55 & 40.44 \\
\hline \multicolumn{7}{|l|}{$\chi^{2}(1, \mathrm{~N}=136)=0.003, \mathrm{~ns}}$. \\
\hline \multicolumn{7}{|c|}{ c. experiencing shyness in the past, but not feeling shyness currently } \\
\hline $\begin{array}{l}\text { teenagers, who experienced shyness in the } \\
\text { past }\end{array}$ & 53 & 79.10 & 41 & 67.21 & 94 & 73.44 \\
\hline $\begin{array}{l}\text { teenagers, who didn't experience shyness in } \\
\text { the past }\end{array}$ & 14 & 20.90 & 20 & 32.79 & 34 & 26.56 \\
\hline \multicolumn{7}{|l|}{$\chi^{2}(1, \mathrm{~N}=128)=2.315, \mathrm{~ns}}$. \\
\hline \multicolumn{7}{|c|}{$\begin{array}{l}\text { feeling a sense of intimidation, despite the declaration that neither currently nor in the past } \\
\text { shyness is/was experienced }\end{array}$} \\
\hline $\begin{array}{l}\text { teenagers, who have ever felt a sense of } \\
\text { intimidations }\end{array}$ & 11 & 78.57 & 18 & 90.00 & 29 & 85.29 \\
\hline $\begin{array}{l}\text { teenagers, who never have felt a sense of } \\
\text { intimidation }\end{array}$ & 3 & 21.43 & 2 & 10.00 & 5 & 14.71 \\
\hline
\end{tabular}

Source: Own research 
The most important conclusion that can be made on the basis of data presented in Table $3(a, b, c)$ relates to wide prevalence of the phenomenon. 230 teenagers among 264 respondents - about $87 \%$, declared that they were currently shy or considered themselves shy in the past. Moreover, it can be noted that over 50\% $(n=136)$ consider themselves shy presently. Nearly $60 \%$ of currently shy teenagers $(n=81)$ could be called chronic shy, which means that in their life there wasn't period when they didn't experienced this feeling.

The two-sided asymptotic significance values $(\mathrm{p}=0.193$ and $\mathrm{p}=0.954)$ of the chi-square test indicate that sex is not statistically significant factor influencing on considering oneself both currently shy and chronic shy.

Another issue, which seems to be important is experiencing shyness in the past by people, who don't consider themselves as shy currently. Analysis of distribution data presented in Table $3 \mathrm{~b}$, leads to make conclusion that there is a large group of teenagers $(n=94)$, who consider themselves as shy previously but no longer. The two-sided asymptotic significance value $(\mathrm{p}=0.128)$ of the chi-square test indicates that there are no statistically significant differences between men and women, who don't consider themselves as shy but previously experienced this phenomenon.

In the context of reflection on the prevalence of shyness it's equally important to analyze experiencing a sense of intimidation by those who neither now nor never previously consider/considered themselves shy. Their huge percentage - over $85 \%(n=29)$ experience/experienced a sense of intimidation that can be identified with a momentary shyness. Differences between men and women aren't statistically significant $(\mathrm{p}=0.354)$.

In the context of the prevalence of shyness in case of contemporary teenagers it's important to pay attention on the teachers' opinions, which were expressed during the conducting research. Every teacher who was present during the lesson, when students were filling in the questionnaire, expressed concern about the success of research related to the fact that in his/her opinion in the class there weren't shy people or were only few. It seems that the confrontation of the results of research and teachers' opinions may be the basis for the conclusion that, in relation to contemporary adolescents we can talk about private shyness (Zimbardo, 2008), which was precisely characterized in one of the part of this paper.

Next research question related to two features of shyness in case of contemporary teenagers - its intensity and stability/variability in experiencing it. Data to make conclusion on the above issues, were collected by asking respondents (who consider/considered themselves shy currently or in the past or have ever experienced a sense of intimidation) two following questions: "How shy are/were you?" and "How does your experiencing of shyness vary depending on the situation?/How did your experiencing of shyness vary depending on the situation?". Collected data were presented in table 4 and table 5 . 
Table 4. Intensity of shyness in case of contemporary teenagers

\begin{tabular}{|l|c|r|r|r|r|r|}
\hline \multirow{2}{*}{} & \multicolumn{2}{|c|}{ women } & \multicolumn{2}{c|}{ men } & \multicolumn{2}{c|}{ Total } \\
\cline { 2 - 7 } & $\mathrm{N}$ & $\%$ & $\mathrm{n}$ & $\%$ & $\mathrm{n}$ & $\%$ \\
\hline $\begin{array}{l}\text { lack of experiencing } \\
\text { shyness }\end{array}$ & 5 & 3.42 & 8 & 7.08 & 13 & 5.02 \\
\hline mild & 52 & 35.62 & 49 & 43.36 & 101 & 39.00 \\
\hline medium & 41 & 28.02 & 31 & 27.43 & 72 & 27.80 \\
\hline quite strong & 27 & 18.49 & 14 & 12.39 & 41 & 15.83 \\
\hline strong & 10 & 6.85 & 7 & 6.19 & 17 & 6.56 \\
\hline very strong & 11 & 7.53 & 4 & 3.54 & 15 & 5.79 \\
\hline
\end{tabular}

$\chi^{2}(5, \mathrm{~N}=259)=5.981, \mathrm{~ns}$.

Source: Own research

Table 5. Stability/variability in experiencing shyness in case of contemporary teenagers depending on the situation

\begin{tabular}{|l|c|c|c|c|c|c|}
\hline \multirow{2}{*}{} & \multicolumn{2}{|c|}{ women } & \multicolumn{2}{c|}{ men } & \multicolumn{2}{c|}{ Total } \\
\cline { 2 - 7 } & $\mathrm{n}$ & $\%$ & $\mathrm{n}$ & $\%$ & $\mathrm{n}$ & $\%$ \\
\hline constancy in experiencing of shyness & 30 & 20.55 & 23 & 20.35 & 53 & 20.46 \\
\hline $\begin{array}{l}\text { low degree of variation in experienc- } \\
\text { ing of shyness }\end{array}$ & 44 & 30.14 & 36 & 31.86 & 80 & 30.89 \\
\hline $\begin{array}{l}\text { moderate degree of variation in expe- } \\
\text { riencing of shyness }\end{array}$ & 32 & 21.92 & 35 & 30.97 & 67 & 25.87 \\
\hline $\begin{array}{l}\text { quite high degree of variation in ex- } \\
\text { periencing of shyness }\end{array}$ & 32 & 21.92 & 13 & 11.50 & 45 & 17.37 \\
\hline $\begin{array}{l}\text { high degree of variation in experienc- } \\
\text { ing of shyness }\end{array}$ & 8 & 5.48 & 6 & 5.31 & 14 & 5.41 \\
\hline $\begin{array}{l}\text { very high degree of variation in expe- } \\
\text { riencing of shyness }\end{array}$ & 0 & 0,00 & 0 & 0,00 & 0 & 0,00 \\
\hline
\end{tabular}

$\chi 2(4, \mathrm{~N}=259)=6.061, \mathrm{~ns}$.

Source: Own research

Analysis of the data contained in Tables 4 and 5 allow to make conclusion, which can be expressed in a statements, that shyness in case of contemporary teenagers is the phenomenon of mild or moderate intensity and of constant nature. Moreover the two-sided asymptotic significance values $(\mathrm{p}=0.308$ and $\mathrm{p}=0.195)$ of the chi-square test indicate that intensity and stability/variability in experiencing of shyness don't depend on sex. 
The issue, which complements the characteristics of shyness in case of contemporary teenagers is their attitude toward the phenomenon. The analysis is based on the following indicators - opinion on the attractiveness of shyness, opinion about liking / disliking shyness, opinion on the perception shyness as a problem. The data were collected by asking respondents about these issues. In the table 6 the data relating to the first indicator were presented.

Table 6. Contemporary teenagers' opinions on attractiveness of shyness

\begin{tabular}{|l|c|c|c|c|c|c|}
\hline \multirow{2}{*}{} & \multicolumn{2}{|c|}{ women } & \multicolumn{2}{c|}{ men } & \multicolumn{2}{c|}{ Total } \\
\cline { 2 - 7 } & $\mathrm{n}$ & $\%$ & $\mathrm{~N}$ & $\%$ & $\mathrm{n}$ & $\%$ \\
\hline shyness as a very undesirable feature & 7 & 4.70 & 11 & 9.57 & 18 & 6.82 \\
\hline shyness as a undesirable feature & 83 & 55.70 & 58 & 50.43 & 141 & 53.41 \\
\hline $\begin{array}{l}\text { no explicit opinion about } \\
\text { attractiveness of shyness }\end{array}$ & 50 & 33.56 & 35 & 30.43 & 85 & 32.20 \\
\hline shyness as a desirable feature & 8 & 5.37 & 6 & 5.22 & 14 & 5.30 \\
\hline shyness as a very desirable feature & 1 & 0.67 & 5 & 4.35 & 6 & 2.27 \\
\hline
\end{tabular}

$\chi 2(4, \mathrm{~N}=264)=6.653, \mathrm{~ns}$.

Source: Own research

The vast majority of respondents $(\mathrm{n}=159)$ think that shyness is an unattractive feature, of which 141 teenagers define it as an undesirable feature and 18 as very undesirable. A relatively large group of people $(n=85)$ cannot clearly indicate whether it is an attractive feature or the opposite. Only for 20 respondents shyness is attractive feature -14 interpret it as desirable and 6 as very desirable. Moreover the two-sided asymptotic significance value $(\mathrm{p}=0.155)$ of the chi-square test indicates that there is no relationship between sex and opinion on attractiveness of shyness.

Another indicator is opinions of respondents who presently or in the past consider/considered themselves shy about liking/disliking it. Data on this issue were presented in table 7 .

Table 7. Opinions of respondents who currently or in the past consider/considered themselves as shy about liking / disliking shyness

\begin{tabular}{|c|c|c|c|c|c|c|}
\hline & \multicolumn{2}{|l|}{ women } & \multicolumn{2}{|l|}{ men } & \multicolumn{2}{|l|}{ Total } \\
\hline & $\mathrm{n}$ & $\%$ & $\mathrm{n}$ & $\%$ & $\mathrm{n}$ & $\%$ \\
\hline liking shyness & 9 & 6.67 & 3 & 3.16 & 12 & 5.22 \\
\hline disliking shyness & 126 & 93.33 & 92 & 96.84 & 218 & 94.78 \\
\hline
\end{tabular}

$\chi 2(1, \mathrm{~N}=230)=1.338, \mathrm{~ns}$.

Source: Own research 
The data contained in the above Table indicate that the vast majority of teenagers $(\mathrm{n}=218, \mathrm{n}=126, \mathrm{n}=92)$, who currently or in the past consider/considered themselves shy don't/ didn't like to experience of this phenomenon. The twosided asymptotic significance value $(\mathrm{p}=0.239)$ of the chi-square test indicates that there are no statistically significant differences between men and women.

In the context of attitude toward shyness, it is also necessary to analyze perceptions of shyness as a problem by teenagers who are or were shy. Collected data were presented in Table 8 .

Table 8. Opinions of respondents who currently or in the past consider/considered themselves as shy, on the perception of shyness as a problem

\begin{tabular}{|l|c|c|c|c|c|c|}
\hline & \multicolumn{2}{|c|}{ women } & \multicolumn{2}{c|}{ men } & \multicolumn{2}{c|}{ Total } \\
\cline { 2 - 7 } & $\mathrm{n}$ & $\%$ & $\mathrm{n}$ & $\%$ & $\mathrm{n}$ & $\%$ \\
\hline $\begin{array}{l}\text { teenagers, who perceive/ } \\
\text { perceived shyness as a problem }\end{array}$ & 92 & 68.15 & 62 & 65.26 & 154 & 66.96 \\
\hline $\begin{array}{l}\text { teenagers, who don't/didn't } \\
\text { perceive shyness as a problem }\end{array}$ & 43 & 31.85 & 33 & 34.78 & 76 & 33.04 \\
\hline
\end{tabular}

$\chi 2(1, \mathrm{~N}=230)=0.210, \mathrm{~ns}$.

Source: Own research

The data contained in Table 8 indicate that majority of teenagers who presently or in the past consider/considered themselves shy, perceive/perceived it as a problem $(n=154, n=92$ and $n=62)$. The two-sided asymptotic significance value $(p=0,647)$ of the chi-square test indicates that there are no statistically significant differences between men and women.

On the basis of above analysis relating to the opinions on attractiveness of shyness, liking/disliking this phenomenon and perceiving it as a problem, it is possible to conclude that contemporary adolescents regardless of sex have rather negative attitude towards shyness. No statistically significant differences between the girls' and boys' attitude to shyness is a relatively important symptom of changes in gender socialization, especially girls. Not long ago according to popular opinion girls should be nice, submissive, rather quiet, non-compete, shy or bashful and boys should be brave, strong, action-oriented and like competition (Mandal, 1995). Both boys' and girls' negative attitude to shyness, is the expression of the opposing to such views and exemplification of changes in patterns of socialization.

An important aspect of shyness in case of contemporary teenagers is also situations, actions, activities and types of people that make them feel shy. Table 9 presents the distribution of all stimuli which were indicated by respondents. 
Table 9. Situations, actions, activities and types of people that make teenagers feel shy

\begin{tabular}{|c|c|c|c|c|c|c|c|}
\hline & \multicolumn{2}{|c|}{ women } & \multicolumn{2}{|c|}{ men } & \multirow{2}{*}{$\begin{array}{l}\text { Asymp. } \\
\text { Sig. } \\
\text { (2 sided) }\end{array}$} & \multicolumn{2}{|c|}{ Total } \\
\hline & $\mathrm{n}$ & $\%$ & $\mathrm{n}$ & $\%$ & & $\mathrm{n}$ & $\%$ \\
\hline $\begin{array}{l}\text { participation in small groups that } \\
\text { work together to perform task }\end{array}$ & 29 & 19.46 & 18 & 15.65 & 0.422 & 47 & 17.80 \\
\hline $\begin{array}{l}\text { participation in small groups } \\
\text { of people that spend free time } \\
\text { together }\end{array}$ & 20 & 13.42 & 17 & 14.78 & 0.752 & 37 & 14.02 \\
\hline $\begin{array}{l}\text { persons of the same sex, } \\
\text { one-to-one }\end{array}$ & 21 & 14.09 & 17 & 14.78 & 0.847 & 38 & 14.39 \\
\hline $\begin{array}{l}\text { persons of the opposite sex, } \\
\text { one-to-one }\end{array}$ & 54 & 36.24 & 46 & 40.00 & 0.532 & 100 & 37.88 \\
\hline $\begin{array}{l}\text { situations in which it is neces- } \\
\text { sary to ask for help, to get some } \\
\text { answers or information }\end{array}$ & 37 & 24.83 & 34 & 29.57 & 0.390 & 71 & 26.89 \\
\hline $\begin{array}{l}\text { contacts with people of higher } \\
\text { social status }\end{array}$ & 48 & 32.21 & 31 & 26.96 & 0.355 & 79 & 29.92 \\
\hline $\begin{array}{l}\text { situations in which assertiveness } \\
\text { is necessary }\end{array}$ & 48 & 32.21 & 27 & 23.48 & 0.119 & 75 & 28.41 \\
\hline $\begin{array}{l}\text { speeches in front of large audi- } \\
\text { ence }\end{array}$ & 100 & 67.11 & 75 & 65.22 & 0.747 & 175 & 66.29 \\
\hline $\begin{array}{l}\text { speeches in front of a small } \\
\text { group }\end{array}$ & 39 & 26.17 & 30 & 26.09 & 0.987 & 69 & 64.39 \\
\hline $\begin{array}{l}\text { assessment or comparison with } \\
\text { others }\end{array}$ & 104 & 69.86 & 66 & 57.39 & 0.037 & 170 & 64.39 \\
\hline contacts with strangers & 55 & 36.91 & 38 & 33.04 & 0.514 & 93 & 35.23 \\
\hline $\begin{array}{l}\text { contacts with persons represent- } \\
\text { ing the authority }\end{array}$ & 25 & 16.78 & 26 & 22.61 & 0.234 & 51 & 19.32 \\
\hline $\begin{array}{l}\text { contacts with authorities and } \\
\text { experts }\end{array}$ & 35 & 23.49 & 20 & 17.39 & 0.226 & 55 & 26.83 \\
\hline
\end{tabular}

Source: Own research

Analysis of the above Table shows that all the stimuli were indicated by a relatively large group of respondents. Recalling own adolescence only a few people would not disagree that in everyday life there are a lot of people, situations or activities, which can make teenagers feel shyness. The most frequent factors are speeches in front of both large audience and a small group as well as situations associated with assessment or comparison with others. It seems that in contemporary teenage life there are a lot of these situations. The most common of them takes 
place when a student stands at the blackboard, the teacher asks questions and his/her classmates listen to. A motive, which is indicated by a fewer but still a large group of respondents is individual contacts with person of opposite sex. Adolescence is the initial phase of the feelings of love (cf. Hurlock, 1965), which causes that the contacts with the opposite sex teenagers at this stage are quite intense.

Respondents answering the question regarding the analyzed issue chose more than one stimulus. Therefore, it's impossible to a use chi-square test jointly for all indications. Therefore it was decided to test presence of differences between men and women on the level of single factors. The two-sided asymptotic significance values (Table 9) of the chi-square test indicate that only in case of one factor - assessment or comparison with others the rejection of null hypothesis (there is no relationship between variables) is possible.

\section{Conclusions and Practical Implications}

Conducted and presented in this paper research, clearly showed that nowadays shyness in case of adolescents, because of its prevalence, is an important problem. Furthermore the phenomenon is associated with many negative consequences experienced by shy person. Zimbardo (2008) and Carducci (2008) believe that the most important are: lack of achieving success in both professional and private life, loneliness and isolation, difficulties in meeting the belonging needs, acceptance and admiration, lack of having fun with social interaction, concentrating on past and future in the absence of skills to focus on the present, alcohol abuse and drug addiction (these substances can be treated as remedies for a sence of inadequacy and lack of acceptance). In addition, shy people sometimes do not reveal their frustration in the form of overt anger, often suppress negative emotions. It can lead to a situation when the accumulated negative feelings suddenly revealed as a crime - rapes and murders.

In this context it seems necessary to take activities which support people, who experience shyness - both chronic and temporary. They can be taken by two the most important environments of upbringing and socialization - family and school.

The implementation of these initiatives will be possible only when parents, teachers, educators and school psychologists will have an extensive knowledge of the complexity of shyness, its causes, types, symptoms and problems related to it but also ways of overcoming this phenomenon of human nature. The modern forms of non-formal education offer a lot of ways to expand the competence in this area. Equally significant are also self-directed learning and reflective and individualized attitude toward each student, both - who seems to be shy and this who in teacher's opinion isn't shy, because we should not be forgotten that many of today's teenagers are private shy. 
Referring part of own research, which shows that shy adolescence believe, that the most effective ways to overcome shyness are: to take participate in some form of social activities, individual work to overcome shyness and self-help group in their school, we can assume, that the support of family and school environment can contribute to increasing the effectiveness of each. For the first of these ways that support may take the form of inspiration and encouragement to start this type of action, convincing of the rightness of the decision or accompaniment to overcome the difficulties and sharing joys with the performance of success. Family and school environment can also help adolescent, who decides to overcome shyness themselves by offering him various books, in which there are described ways to deal with shyness as well as offering emotional and esteem support. Formation self-help groups can be initiated by school staff, who later may be their facilitators, support their action, help to overcome the difficulties and problems.

Family and school may also be significant in the implementation of the two most important priorities in the struggle with shyness. The first is the identification, which is defined as understanding what shyness is for a person, influence of this phenomenon on someone's life and finding areas in which most disturbs someone's behavior. It gives a good basis for a rational program of intervention, therapy and change (Zimbardo, 2008; Carducci 2008). In this context, the role of family and school may be expressed in complement the teenagers' knowledge about the shyness, its causes, symptoms, myths and misunderstandings about this phenomenon. Moreover they should help to understand adolescents that they can overcome it, change their behavior, thoughts and emotions. Parents, siblings, teachers, educators and school psychologists can also propose/show tools that can contribute to the identification of shyness - questionnaires and diaries of shyness and provide assistance in understanding shyness adequate to the needs of a teenagers.

The second priority is incorporation, which is understood as the acceptance of shyness and integration the truth about it in all life decisions. It is associated with two important concepts by Carducci (2008) - a positive shy life and positively shy people. The first of these terms relates to the life that on one side does not ignore the consequences of shyness in the form of pain and suffering, on the other hand contains rational strategies for coping in difficult situations. The second characterizes people who have more realistic and forgiving views about shyness and ways to control it, are no longer the victims of it, they understand that they must develop functional strategies for the modification of their behavior. Support offered by the family and the school environment can be expressed in promoting these concepts and the accompaniment of a teenager in a struggle, which goal is to on one side the acceptance of shyness, on the other, developing rational strategies to deal with it.

Because of the fact that shyness and low self-esteem correlate strongly with each other, an important priority in overcoming shyness is to build self-esteem (cf. Carducci, 2008; Dzwonkowska, 2009; Harwas - Napierala, 1995, Lowndes, 2007; Łamek 2009; Tyszkowa, 1978, 1993; Zimbardo, 2008). This is another area in 
which support can be implemented both in a family and school environments by showing adolescents their strengths, assist in setting realistic goals and achieving them, build a sense of efficacy and learning skills of multi-faceted interpretation the apparently unfavorable situations.

No less important also seems to give teenagers support in developing social skills, e. g. by creating social interaction. Moreover family and school environments can encourage teens to seek in the literature ways to develop their social skills or introduce those proposed by Zimbardo (2008) and encourage them the implementation (2008): role-playing, practicing interview skills while waiting in queue.

In presented paper, the subject of analysis was the characteristic of shyness in case of contemporary teenagers. However, another important issue can be to consider the forms of prophylaxis that could counteract the appearance and consolidation of shyness in children, then adolescents, and adults. Without doubts, this issue may be inspiration for further research, analysis and papers on shyness.

\section{References}

Borecka-Biernat D.( 2001). Zachowanie nieśmiałe młodzieży w trudnej sytuacji społecznej. Kraków: Oficyna Wydawnicza Impuls.

Carducci B. (2008). Nieśmiałość - nowe odważne podejście. Kraków: Wydawnictwo Znak.

Gerstmann S. (1963). Uczucia w naszym życiu. Warszawa: Wiedza Powszechna.

Harwas-Napierała B. (1979). Nieśmiałość dziecka. Poznań: UAM.

Harwas-Napierała B. (1995). Nieśmiałość dorostych - geneza, diagnostyka, terapia. Poznań: Wydawnictwo Fundacji Humaniora.

Henderson L., Zimbardo P.: Shyness. www.shyness.com, [20.10.2012]

Kędzierska B., Znajmiecka-Sikora M., Kaflik-Pieróg M. (2002). Nieśmiałość - określenie zjawiska oraz doniesienie wstępne z badań. Zeszyty Naukowe WSHE w Łodzi, 1, p. $71-82$.

Kędzierska B., Znajmiecka-Sikora M., Kaflik-Pieróg M. (2003). Nieśmiałość - doniesienie wstępne z badań. Zeszyty Naukowe WSHE w Łodzi, 1, p. 97 - 108.

Konieczna M., Paryzek L.: Zależność między nieśmiałością a sugestywnością. Neodigmata, 1974, $n r 6, p .155-164$;

Mead M. (2000). Kultura i tożsamość - studium dystansu międzypokoleniowego. Warszawa: Wydawnictwo Naukowe PWN.

Melosik Z. (2007). Kultura popularna jako czynnik socjalizacji [In:] Kwieciński Z., Śliwerski B. [Eds.]. Pedagogika - podręcznik akademicki. Warszawa: Wydawnictwo Naukowe PWN., p. $68-93$;

Melosik Z. (2005). Młodzież a przemiany kultury współczesnej [In:] Leppert R., Melosik Z., Wojtasik B. [red.]: Młodzież wobec niegościnnej przyszłości. Wrocław: Wydawnictwo Naukowe Dolnośląskiej Szkoły Wyższej Edukacji TWP, p.12-31;

Zabłocka M. (2008). Przezwyciężanie nieśmiałości u dzieci. Warszawa: Wydawnictwo Naukowe Scholar.

Zawadzka E. (2010). Analiza zjawiska nieśmiałości wspótczesnych nastolatków na podstawie badań przeprowadzonych wśród tódzkich adolescentów. Łódź: Unpublished thesis.

Zimbardo P.G. (2008). Nieśmiałość - co to jest? jak sobie z nia radzić? Wydawnictwo Warszawa: Naukowe PWN. 